Свген Першин

ORCID: orcid.org/0000-0003-1491-2863

DOI 10.31558/1815-3070.2021.42.7

УДК 8142: 811.161.2

\title{
КАТЕГОРІЯ САСПЕНСУ В МІСТИЧНОМУ ХУДОЖНЬОМУ ДИСКУРСІ: ІНТЕНЦІЙНИЙ АСПЕКТ (НА МАТЕРІАЛІ РОМАНУ «ГРИМУЛЯ» А. ЗАКОРДОНЦЯ)
}

Статтю присвячено вивченню категорії саспенсу у містичному художньому дискурсі. Проаналізовано висвітлення поняття «саспенс» у наукових прачях вітчизняних дослідників. Виявлено лексичні та синтаксичні засоби вираження иієї текстової категорії у містичній прозі. Наведено приклади реалізаиії авторської інтенції як комунікативної стратегії текстотворення.

Ключові слова: містичний художній дискурс, містична проза, категорія «саспенс», інтенція, комунікативна стратегія текстотворення, сучасна украйнська література.

Актуальність теми та постановка проблеми в загальному вигляді. Наразі дослідження художнього дискурсу виконуються з опертям на текстово-дискурсивний підхід, що має на меті виокремлення та дескрипцію текстових категорій і їхнього комунікативного потенціалу. Деякі із них є універсальними і характеризують твори різних жанрових форм, а деякі притаманні лише окремим типам дискурсу (Селиванова 2015). Так, дослідники, чиї наукові інтереси направлені на дослідження художніх текстів, звертають увагу на категорію саспенсу, яка все частіше актуалізується сьогодні у таких популярних жанрах, як горор, фентезі і детектив. Саме тому у центрі нашої уваги постала ця текстова категорія і засоби iii реалізації у містичному художньому дискурсі, оскільки в сучасній лінгвістиці відсутнє комплексне дослідження, присвячене аналізу саспенсу у містичній прозі.

Метою статті є витлумачення категорії «саспенс» та висвітлення вербальних маркерів іiі реалізації у містичному художньому дискурсі, що потребує розв’язання таких завдань: 1) дати дефініцію категорії саспенсу та зазначити її основні характеристики; 2) виявити лінгвістичні способи реалізації цієї категорії у містичному художньому дискурсі; 3) схарактеризувати комунікативний намір автора щодо використання вербальних репрезентантів категорії саспенсу.

Об’єктом нашого дослідження є категорія саспенсу у містичному художньому дискурсі, а предметом - мовні засоби їі вираження у містичній прозі.

Матеріалом для аналізу слугував роман «Гримуля», що належить перу сучасного українського письменника-містика А. Закордонця.

У статті використано такі загальнонаукові методи: описовий, за допомогою якого було виокремлено мовні одиниці в проаналізованому романі, методи аналізу і синтезу, за допомогою яких систематизовано зібраний матеріал та узагальнено отримані результати. Серед спеціальних лінгвістичних методів залучено: метод контекстуально-інтерпретативного аналізу, який використано для визначення функціонального навантаження мовних одиниць; елементи дискурс-аналізу - для їхньої комунікативно-прагматичної інтерпретації. 
Наукова новизна статті полягає у тому, що в ній вперше здійснено дослідження особливостей реалізації категорії саспенсу у містичному художньому дискурсі на матеріалі сучасної української літератури.

Теоретична цінність полягає в тому, що стаття становить певний внесок у дослідження художнього дискурсу. Зокрема, схарактеризовано основні лінгвістичні засоби лексичної та синтаксичної репрезентації категорії саспенсу в містичній прозі. Запропонована методика може бути використана під час аналізу інших жанрів художнього дискурсу.

Практична цінність одержаних результатів зумовлена можливістю їхнього використання для створення навчальних і навчально-методичних посібників із лінгвістики художнього тексту, для розроблення навчальних курсів і спецкурсів із художньої комунікації.

Ступінь дослідження проблеми. Проблема вивчення категорії саспенсу в містичному художньому дискурсі (далі - МХД) характеризується відсутністю наукових розвідок у лінгвістиці. Натомість поодинокі статті літературознавчого характеру зосереджено на реалізації цієї категорії в інших жанрах мистецтва. Так, спробу витлумачення і становлення категорії «саспенс» у художньому і кіно-дискурсі знаходимо в статтях І. Ю. Задерій (Задерій 2015), А. В. Лещенко (Лещенко 2014), Н. Л. Самосюк (Самосюк 2014), С. А. Суханової (Суханова 2016); жанрово-стильові й теоретико-методологійні підвалини дослідження реалізації цієї категорії у художніх творах відбито в роботах О. С. Божко (Божко 2017), А. С. Галич (Галич 2017), І. І. Могілей (Могілей 2014), Н. Л. Самосюк (Самосюк 2014); комунікативні техніки створення саспенсу описані у працях I. Г. Жогової (Жогова 2018), М. Є. Обнорської та Є. В. Полосіної (Обнорская, Полосина 2009). 3 огляду на це, питання щодо лінгвістичних засобів вираження категорії саспенсу в містичному художньому дискурсі потребує грунтовного висвітлення.

Викладення основного матеріалу дослідження. Як справедливо зазначає I. Г. Жогова, «незважаючи на те що термін “саспенс" все частіше зустрічається у вітчизняній лінгвістиці і літературознавстві, чіткої дефініції поняття поки що не існує» (Жогова 2018: 48). А. В. Лещенко причиною цього вважає «комплексний характер аналізованого поняття, опис якого вимагає залучення концептуальнометодологійного інструментарію інших галузей знання - психології, наратологіi, когнітивної поетики, психолінгвістики, літературознавства, рецептивної естетики тощо» (Лещенко 2014: 55).

Термін «саспенс» походить від латинського «suspensus», що буквально означає «завмерлий, застиглий, закляклий, натягнутий», тобто йдеться про стан непевності, невідомості, неспокою, невирішеності, тривоги (Эйдис 2012).

За словниковою статтею, поданою у СУМ, саспенс - це: 1 . Стан тривожного очікування, хвилювання, напруження; 2. У кінематографі, відеоіграх, літератуpi - художній ефект, особливий тривалий тривожний стан глядача або читача при перегляді фільму або читанні книги; 3. Набір художніх прийомів, який використовується для досягнення цього ефекту (СУМ).

На думку І. Ю. Задерій, саспенс - «це художній ефект, спрямований на утримання реципієнта художнього твору в емоційному стані напруженого очікування» (Задерій 2015: 18). О. С. Божко зазначає, що категорію саспенсу покладено в 
основу містичних та горор творів як таких, що створюють атмосферу загадковості, невизначеності, примарності. На думку дослідниці, метою цієї літературної категорії $\epsilon$ «забезпечення гострих почуттів та утримання аудиторії у напруженні у той час, як сюжет вибудовується до кульмінаційного моменту» (Божко 2017: 52).

Мовознавиця Т. В. Юдіна визначає саспенс як змістовну категорію художнього тексту, пов'язану із авторською інтенцією створити напругу, викликати у реципієнта страх або занепокоєння (Юдина 1990).

Такої ж думки дотримується А. В. Лещенко: «У власне лінгвістичному трактуванні саспенсом йменується створення наративної напруги з метою інтенсифікації інтересу читача до того, що буде відбуватися далі» (Лещенко 2014: 55). Спираючись на психологічний підхід, вона пропонує розглядати саспенс як емоційну реакцію на наратив, що грунтується на трьох афективних компонентах: невизначеність, передчуття (очікування) та емоційна співпричетність. Останній пов’язаний із виявом емпатії щодо протагоніста і наявністю у реципієнта парних емоцій - страху та надії (Лещенко 2014: 56). На нашу думку, саме таку функцію емоційного наративу категорія саспенсу і виконує у текстах художнього містичного дискурсу.

I. I. Могілей щодо цього зазначає, що саспенс є однією з основних дискурсивних одиниць тексту, яка пов'язана із його напруженістю та зацікавленістю читача і яка «формує засади більшості сюжетів всесвітнього літературного дискурсу і $є$ вичерпним аргументом на користь популярності твору та незмінного читацького інтересу до нього» (Могілей 2014: 92). Серед основних характеристик цієї категорії вона називає: трансляцію почуття страху, тривогу, спричинену постійним очікуванням розв'язки, хвилювання за долю персонажа (Могілей 2014: 92).

О. П. Воробйова вказує на амбівалентність категорії саспенсу. 3 одного боку, це «емотивний компонент літературної оповіді» (Воробьёва 2000: 123), на якому будується сюжет, розвиток основного конфлікту та потенційна розв'язка; з іншого, це «емоційна реакція читача на літературний текст», яка грунтується на проспектно-орієнтованому стані невизначеності й напруженості щодо можливого вирішення тих чи тих колізій художньої дійсності (Воробьёв 2000: 123). Зважаючи на це, можна вважати, що категорія саспенсу має значний текстотвірний потенціал.

Отже, резюмуючи, можна сказати, що категорія саспенсу в МХД - це одна 3 текстотвірних категорій, яка характеризується використанням вербальних знаків задля утримання реципієнта в емоційному стані напруження, хвилювання i страху, що зумовлено авторською інтенцією.

Передача саспенсу, як зазначає $Є$. А. Суханова, відбувається шляхом навіювання, сугестії, під якою розуміють ототожнення реципієнтом свого психофізичного стану із станом героя художнього твору (Суханова 2016: 140). Як відзначено в низці наукових розвідок, у художніх текстах реалізація цієї категорії відбувається за допомогою набору певних емоційно забарвлених лексичних та синтаксичних одиниць (Божко 2017; Галич 2017; Жогова 2018; Могілей 2014).

На лексичному рівні, на думку І. Г. Жогової, створенню саспенсу і наростанню атмосфери занепокоєння у творах сприяє техніка ампліфікації, або нагнітання, за рахунок використання повторів значень або сем (Жогова 2018: 49). 
О. С. Божко виокремлює лексеми, що «анатомують страх, подають, свого роду, його «фізіологію», аналізують стани афекту, напр.: страх, жах, шок, паніка тощо» (Божко 2017: 53). Іноді емоційність таких лексем, що характеризують стан людини після зіткнення з надприродними явищами і химерами, може підсилюватися епітетами з негативною конотацією, напр.: жахливий, страшний, невиразний, несамовитий тощо (Божко 2017: 53).

Окрім цього, А. С. Галич на лексичному рівні також фіксує фразеологічні звороти, що $є$ репрезентантами категорії санспенсу, напр., для передачі відчуття страху можуть використовуватися такі фразеологізми: кров холоне (у жилах), мороз ходить спиною тощо (Галич 2017: 42).

I. Г. Жогова стверджує, що великий внесок у створення саспенсу в художніх творах вносять синтаксичні засоби: компресія мовних засобів сприяє напруженості, гостроті оповідання. У якості таких вона називає односкладні, еліптичні і уривчасті пропозиції (Жогова 018: 31).

На синтаксичному рівні дослідниця А. С. Галич також фіксує такі вияви категорії саспенсу:

1) словосполучення і речення, що, наслідуючи готичний та химерний романи, змальовують пейзаж як «таємничий і такий, що вселяє атмосферу страху» (Галич 2017: 47);

2) речення на позначення розумової, вербальної та жестової діяльності персонажа у незвичній ситуації (Галич 2017: 45);

3) емоційно забарвлені та перервані речення як засіб оцінного впливу на читача (Галич 2017: 56).

Простежимо вербальні маркери реалізації категорії саспенсу в романі А. Закордонця «Гримуля».

На лексичному рівні фіксуємо і об'єднуємо у лексико-семантичне поле «страх» слова та їхні словоформи, що вживаються на позначення і передачу страху, напруження, тривожного очікування. Задля повного опису цього лексико-семантичного поля звернімося, по-перше, до словників синонімів. Лексема «страх» має такі синоніми: жах, переляк, тривога, острах, моторошність, перестрах, загроза, боязнь (Караванський 2014).

По-друге, звернімося до вільного асоціативного експерименту, проведеного О. О. Коляденко у 2018 році задля опису структури концепту «страх». У перебігу його проведення дослідниця виявила, що лексико-семантичне поле «страх» peaлізується через такі лексеми, що позначають:

1) колоративи: чорний, червоний, яскраві кольори;

2) слухові відчуття: крик, тиша як каузатори емоційного стану, а також одиниці, що відтворюють вербальну реакцію;

3) одоративні: сморід;

4) тактильні відчуття: мурашки по шкірі, липкий піт, сльози;

5) больові: біль;

6) температурні відчуття: холод, жар;

7) чуттєвість від внутрішніх органів: прискорене серцебиття, внутрішній дискомфорт, голод, перехопило подих, все єство згортається в клубок; 
8) м'язова чуттєвість: тремтіння / в ногах;

9) вестибулярна чуттєвість: висота, глибина, швидкість;

10) образи-конотативи (ментальні образи фізичних дій): тікати, ховатися, метушня, завмерти;

11) оцінні образи із раціональною негативною оцінною семантикою: біль, смерть, зрада, слабкість;

12) наочно відтворювані образи-картинки, які можуть сприйматися як загрозливі: павук, змія, цвинтар, темна (порожня) кімната тощо;

13) архетипи (генетично успадковані структури знання): темрява (ніч), вода, вогонь (полум'я), смерть, блискавка, землетрус.

Отже, створенню особливого емоційного фону і нагнітанню атмосфери в романі «Гримуля» сприяє використання повторів таких значень або сем лексикосемантичного поля «страх»:

- страх: «Але то йому, звичайно, привиділося з великого переляку ...»; або «... і стало зрозуміло, що страх тільки починається»; або «Але то був не протяг, ні. Щось значно гірше і набагато страшніше»; або «Потягнуся, наче зі сну, вигнув спину, випустив страхітливі пазурі на лапах»; або «Як страшно іноді буває навіть уявити правду, навіть здогадуватися про неї!»; або «Знайоме загальне заціпеніння. А далі заціпеніла вихователька, бо почалося неочікуване й дивне»; або «Таня перелякано зиркнула на Сергія»;

- холод: «Чомусь пройшовся спиною холодок, навіть коліна затремтіли»; або «Аж мороз шкірою»; або «Вся така поважна й неприступна, навіть не скажеш, що тремтить»;

- тиша: «Це було страшніше, аніж будь-який гвалт, люди у вікнах заціпеніли, вражені раптовою тишею і жаским очікуванням миті, коли ця тиша вибухне»; або «Раптом запала тиша. Тиша, яка лякала, тиша, яка чекала»; або «Навколо стояла мертва тиша»; або «Глухо гупнуло, схитнуло в'язку тишу передмістя, одразу кілька собак з породи шавок заголосили...»; або «Аж мороз шкірою, - прошепотів Сергій».

Також лексико-семантичне поле «страх», що є вербальною реалізацією категорії саспенсу у МХД, представлено образами-конативами, що реалізують ментальні образи фізичних дій: «Забагато страху вже не сприймається, мозок просто перестає вірити в почуте»; або «Діти завмерли, застигли, хто де був і хто чим бавився».

Варто зауважити, що авторська інтенція щодо репрезентації категорії санспенсу є амбівалентною. Так, уживання перших двох лексико-семантичних груп пов'язано із метою передати почуття героїв роману, зокрема страх, викликаний зустріччю із незрозумілим і химерним. Уживання останніх не тільки змальовує переживання персонажів, змушуючи реципієнта ототожнювати себе із ними, але й налаштовує значною мірою на різкий сюжетний поворот, вводить у стан тривожного очікування.

На синтаксичному рівні категорія саспенсу представлена експресивно забарвленими і перерваними реченнями:

1) експресивно забарвленими реченнями $\epsilon$ окличні, у яких, як зазначає А. П. Загнітко, «сконденсовано емоційно-експресивне забарвлення, передається 
емоційно-почуттєвий стан мовця» (Загнітко 1996: 454). У творах МХД, звичайно, це стан саспенсу. Як справедливо нагадує А. П. Романченко, експресивні речення мають специфічне пунктуаційне маркування - знак оклику (Романченко 2019: 287): «Злі очі!»; або «А далі взагалі капєц!»; або «Хуг, наче забралося. Хоча, хто його зна, спаси Господи!»; або «Стій! - вона схопила хлопця за руки 3 такою силою, що той ошелешено завмер»;

2) перервані (незакінчені) речення мовознавець А. О. Загнітко трактує як такий тип конструкцій, що передусім $є$ «важливим засобом оформлення думки, засобом відтворення почуттів і відношень мовця до зображуваного явища, особи і подій» (Загнітко 2014: 323). На нашу думку, використання перерваних речень у МХД пов'язано із тим, що вони допомагають передати емоції страху, розгубленості, відчаю та тривоги, які практично впродовж усього роману відчувають герої: «Справді страшно...»; або «Щось у повітрі, в мовчанні вашому, і коли говорите...»; або «Десь вона вже бачила цю посмішку...»; або «Вона вже навіть у темряві, навіть під ковдрою не може сховатися від великого і страшного, бо ворони із ним змовилися...»

Авторська інтенція у зазначених прикладах полягає у тому, щоб увести читача у стан напруги, навіяти йому певний емоційний стан, змусити його повірити у зображуване.

Висновки і перспективи дослідження. Можемо з певністю сказати, що категорія саспенсу має свої особливості вираження у текстах містичної прози. На лексичному рівні вона реалізується за допомогою лексико-семантичних груп на позначення страху, тривоги, напруженого очікування; на синтаксичному - за допомогою семантично, емоційно-забарвлених та перерваних речень. Подальші перспективи дослідження пов'язані з вивченням вербальної реалізації категорії саспенсу у інших текстах містичного художнього дискурсу та побудовою стрункої класифікації.

\section{Література}

1. Божко, О. С. «Атмосфера “саспенс" як домінантна ознака літературного жанру “фентезі”» [B:] Наукові записки Наиіонального університету «Острозька академія». Серія «Філологічна» 67, 2017: 51-54.

[Bozhko, O. S. «Atmosfera "saspens" yak dominantna oznaka literaturnoho zhanru "fentezi"» [V:] Naukovi zapysky Natsionalnoho universytetu «Ostrozka akademiia». Seriia «Filolohichna» 67, 2017: 51-54.]

2. Воробьёва, О. П. «Сюжетное напряжение сквозь призму конфликта ментальных пространств (опыт концептуального анализа)» [В:] Когнитивная семантика : материалы второй международной иколы-семинара, 2000: 123-125.

[Vorobyeva, O. P. «Syuzhetnoye napryazheniye skvoz prizmu konflikta mentalnykh prostranstv (opyt kontseptualnogo analiza)» [V:] Kognitivnaya semantika: materialy vtoroy mezhdunarodnoy shkoly-seminara, 2000: 123-125.]

3. Галич, А. С. Стилистические особенности жанра хоррор в литературе (на материале рассказов О. Кироги). СПб. : Санкт-Петербургский государственный ун-т, 2017. 68 с.

[Galich, A. S. Stilisticheskiye osobennosti zhanra khorror v literature (na materiale rasskazov O. Kirogi). SPb. : Sankt-Peterburgskiy gosudarstvennyy un-t. 2017. 68 s.] 
4. Жогова, И. Г. «Языковые средства создания саспенса в произведениях жанра “триллер” и способы их актуализации (на материале романов англоязычных авторов)» [В:] Язык $u$ культура 43, 2018: 46-57.

[Zhogova, I. G. «Yazykovyye sredstva sozdaniya saspensa v proizvedeniyakh zhanra "triller" i sposoby ikh aktualizatsii (na materiale romanov angloyazychnykh avtorov)» [V:] Yazyk i kultura 43, 2018: 46-57.]

5. Загнітко, А. П. Теоретична граматика української мови. Морфологія. Донецьк : ДонДУ, 1996. $437 \mathrm{c}$.

[Zahnitko, A. P. Teoretychna hramatyka ukrainskoi movy. Morfolohiia. Donetsk: DonDU, 1996. $437 \mathrm{s.}]$

6. Загнітко, А. П. Теорія граматики і тексту: монографія. Донецьк : ДонНУ, 2014. 480 с.

[Zahnitko, A. P. Teoriia hramatyky i tekstu: monohrafiia. Donetsk : DonNU, 2014. 480 s.]

7. Задерій, I. Ю. «Ефект саспенсу й вирішення його драматичних репрезентацій» [В:] Одеський лінгвістичний вісник 6, 2015: 18-21.

[Zaderii, I. Yu. «Efekt saspensu y vyrishennia yoho dramatychnykh reprezentatsii» [V:] Odeskyi linhvistychnyi visnyk 6, 2015: 18-21.]

8. Закордонець, А. Гримуля : роман. Вінниця: Дім Химер, 2019. 176 с.

[Zakordonets, A. Hrymulia : roman. Vinnytsia: Dim Khymer, 2019. 176 s.]

9. Караванський, С. Й. Практичний словник синонімів української мови. 5-те вид., опрацьоване і доповн. Львів : БаК, 2014. 530 с.

[Karavanskyi, S. Y. Praktychnyi slovnyk synonimiv ukrainskoi movy. 5-te vyd., opra-tsovane i dopovn. Lviv : BaK, 2014. 530 s.]

10. Коляденко, О. О. Лексико-семантична репрезентація концепту «страх» в українській наївній та науковій картинах світу: дис. ... доктора філософії : 10.02.01. Київ, 2018. 219 с.

[Koliadenko, O. O. Leksyko-semantychna reprezentatsiia kontseptu «strakh» v ukrainskii naivnii ta naukovii kartynakh svitu: dys. ... doktora filosofii : 10.02.01. Kyiv, 2018. 219 s.]

11. Лещенко, А. В. «Понятие саспенса в контексте современных научных исследований» [В:] Science and Education a New Dimension. Philology II(6), 2014: 55-57.

[Leshchenko, A. V. «Ponyatiye saspensa v kontekste sovremennykh nauchnykh issledovaniy» [V:] Science and Education a New Dimension. Philology II(6), 2014: 55-57.]

12. Могілей, I. I. «Ідіостилістична організація перекладацького дискурсу у творах художньої літератури жанру саспенс» [B:] Вісник Черкаського університету. Серія : Філологічні науки 27, 2014: C. 91-96.

[Mohilei, I. I. «Idiostylistychna orhanizatsiia perekladatskoho dyskursu u tvorakh khudozh-noi literatury zhanru saspens» [V:] Visnyk Cherkaskoho universytetu. Seriia : Filolohichni nauky 27, 2014: S. 91-96.]

13. Обнорская, М. Е., Полосина, Е. В. «Техника создания саспенса в романах М. Стюарт» [B:] MHKO 4, 2009: 29-33.

[Obnorskaya, M. E. Polosina, E. V. «Tekhnika sozdaniya saspensa v romanakh M. Styuart» [V:] MNKO 4, 2009: 29-33.]

14. Романченко, А. П. Елітарна мовна особистість у просторі наукового дискурсу: комунікативні аспекти: монографія. Одеса : Одеський національний університет імені I. I. Мечникова, 2019. $541 \mathrm{c.}$

[Romanchenko, A. P. Elitarna movna osobystist u prostori naukovoho dyskursu: komunikatyvni aspekty: monohrafiia. Odesa : Odeskyi natsionalnyi universytet imeni I. I. Mechnykova, 2019. $541 \mathrm{s.]}$

15. Самосюк, Н. Л. «Принцип саспенса и литературная фактура настроения (на примере романа Майкла Крайтона “Парк Юрского периода")» [B:] Austrian Journal of Humanities and Social Sciences 5-6, 2014: 204-209.

[Samosyuk, N. L. «Printsip saspensa i literaturnaya faktura nastroyeniya (na primere romana Maykla Kraytona "Park Yurskogo perioda")» [V:] Austrian Journal of Humanities and Social Sciences 5-6, 2014: 204-209.] 
16. Селиванова, Е. А. «Текстово-дискурсивные категории кроссворда как жанра энигматики» [B:] Мова 24, 2015: 30-39.

[Selivanova, E. A. «Tekstovo-diskursivnyye kategorii krossvorda kak zhanra enigmatiki» [V:] Mova 24, 2015: 30-39.]

17. СУМ в 11 томах. URL: https://cutt.ly/RmhPvNQ (31.08.2021).

[SUM v 11 tomakh. URL: https://cutt.ly/RmhPvNQ (31.08.2021).]

18. Суханова, Е. А. «Типология и характерные черты хоррор-дискурса» [В:] Филологические науки. Вопросы теории и практики 6 (60), 2016: 139-142.

[Sukhanova, E. A. «Tipologiya i kharakternyye cherty khorror-diskursa» [V:] Filologicheskiye nauki. Voprosy teorii i praktiki 6 (60), 2016: 139-142.]

19. Эйдис, М. «Что такое саспенс?», 2012. URL : https://cutt.ly/3mhPxZ0 (31.08.2021).

[Eydis, M. «Chto takoye saspens?», 2012. URL : https://cutt.ly/3mhPxZ0 (31.08.2021).]

20. Юдина, Т. В. Категория напряженности и средства ее выражения: автореф. дис. ... канд. филол. наук : 10.02.04. Ленинград, 1990. 17 с.

[Yudina, T. V. Kategoriya napryazhennosti i sredstva eye vyrazheniya: avtoref. dis. ... kand. filol. nauk : 10.02.04. Leningrad, 1990. 17 s.]

\section{THE CATEGORY OF SUSPENSE IN MYSTICAL FICTION DISCOURSE: INTEN- TIONAL ASPECT (ON THE MATERIAL OF THE NOVEL "GRIMUL" BY A. ZAKOR- DONETS)}

\section{Yevhen Pershyn}

Department of Applied Linguistics, Odesa Mechnikov National University, Odesa, Ukraine.

\section{Abstract}

Background: Studies of the category of suspense as a special anxious state of the recipient is gaining popularity today, since it allows the author to build the further narrative in the necessary direction. Many linguistic investigations in this area are carried out on the basis of the theory of speech genres with the involvement of text-discursive approach. These studies are devoted to highlight the category of suspense in cinematography and horror literature and related, first of all, to the lexico-semantic level of language. However, the manifestation of this textual category in the texts of mystical prose remains unattended, both at the level of semantics and at the level of pragmatics.

Purpose: The aim of the article is to determine the category of suspense and highlight the verbal markers of its implementation in the mystical fiction discourse.

Results: We can say with certainty that the category of suspense has its own features of expression in the texts of mystical prose. At the lexical level, it is realized with the help of lexicalsemantic groups to denote fear, anxiety, intense anticipation; at the syntactic level it manifests through emotionally colored and interrupted sentences. It is worth noting that the author's intention of representation the category of suspense is ambivalent. The author either aims to convey the feelings of the heroes of the novel, in particular the fear caused by the encounter with the incomprehensible and bizarre, or sets the reader to a sharp plot twist, puts him in a state of anxious anticipation.

Discussion: The study of text categories is usually supplemented new methods and approaches. We have proposed a textual-discursive as one that allows highlight the author's intention. The problem of realization of the category of suspense requires further coverage in fiction mystical texts with the involvement of various approaches.

Conclusion: Our findings suggest that (1) the category of suspense has its own features of expression in the texts of mystical prose both at the lexical level and at the syntactic level; (2) the implementation of the author's intention of the category of suspense is a text-forming category for mystical prose; (3) the category of suspense should stay in the field of scientific interest, because stylistic and pragmatic features of these works have not been studied.

Keywords: mystic fiction discourse, mystic prose, the category of suspense, intention, communicative strategy, modern Ukrainian literature. 
Vitae

Yevhen Pershyn is $\mathrm{PhD}$ student of the department of Applied Linguistics Odesa Mechnikov National University. His areas of research interests include text linguistics, pragmalinguistics, political linguistics, communicative linguistics, morphology, word formation.

Correspondence: y.pershyn@onu.edu.ua

Надійшла до редакції 3 вересня 2021 року Рекомендована до друку 19 жовтня 2021 року 